\title{
PENGARUH PEMBERIAN PUPUK ORGANIK CAIR (AIR LINDI) TERHADAP PERTUMBUHAN MORFOMETRIK TANAMAN SELEDRI (Apium graveolensi $\mathrm{L}$ )
}

\section{THE EFFECT OF LIQUID ORGANIC FERTILIZER (WASTE WATER LEACHATE) ON MORPHOMETRIC GROWTH OF THE CELERY PLANT (Apium graveolens $\mathrm{L}$ )}

\author{
Mar Ayunis $^{1}$, Lani Puspita ${ }^{2}$, Notowinarto ${ }^{2}$ \\ ${ }^{1}$ Alumni Program Studi Pendidikan Biologi, FKIP, Universitas Riau Kepulauan, Batam \\ ${ }^{2}$ Dosen Program Studi Pendidikan Biologi, FKIP, Universitas Riau Kepulauan, Batam
}

Koresponden:lanipuspita@gmail.com

\begin{abstract}
Abstrak
Limbah cair sampah yang disebut air lindi memiliki potensi sebagai pupuk organik cair yang dapat digunakan untuk pupuk tanaman. Tujuan penelitian untuk melihat efek pemberian air lindi terhadap pertumbuhan morfometrik tanaman Seledri (Apium graveolens L). Pengujian dilakukan dengan membandingkan dengan menggunaan pupuk cair komersial yang biasa oleh petani. Hasil pengujian yang diperoleh dengan derajat gain tinggi kebebasan 18 dan tingkat kepercayaan 95\% atau $\alpha=0,05$. T tabel 1.734 dan $\mathrm{T}$ hitung adalah 0,92 ( $\mathrm{T}$ hit $0,92<\mathrm{T}$ tab 1,73). Nilai $\mathrm{T}$ hitung $<\mathrm{T}$ tabel. Hipotesis $\mathrm{H}_{0}$ diterima, $\mathrm{H}_{\mathrm{i}}$ ditolak, artinya pupuk organik cair lindi tidak memiliki efek yang sama dengan organik cair atau pupuk cair lindi tidak memberikan efek yang lebih baik.
\end{abstract}

Kata Kunci: Pupuk organik cair, pertumbuhan morfometrik, Tanaman Seledri (Apium graveolens L)

\section{Abstract}

Liquid waste bins called leachate has the potential as a liquid organic fertilizer which can be used to fertilize crops. Research purposes to see the effects of leachate on the growth of plants morphometric Celery (Apium graveolens L). The exsperiment is done by comparing the uses commercial liquid fertilizer commonly by farmers. The results were obtained with a high degree of freedom 18 and gain confidence level of $95 \%$ or $\alpha=0.05$. $T$ table 1.734 and $T$ count is 0.92 (T count $0.92<T$ table 1.73). That value $H_{0}$ accepted, Hi rejected, meaning that the liquid organic fertilizer leachate does not have the same effect with the organic liquid or liquid fertilizer leachate does not give a better effect.

Keywords: Liquid organic fertilizer leachate, morphometric growth, Celery (Apium graveolens L)

\section{PENDAHULUAN}

Semakin meningkatnya jumlah penduduk di kota Batam dengan segala aktifitasnya, jumlah sampah yang dihasilkanpun terus meningkat. Sampah yang dihasilkan berasal dari aktifitas pemukiman, sampah pasar, sampah pertokoan, sampah fasilitas umum, dan sampah industri. Luas tempat pembuangan akhir sampah Telaga Punggur kurang lebih 46 hektar dengan sistim penanganan sampah menggunakan Controlled landfill. Setiap hari menerima 771,71 m³/hari sampah yang menimbulkan dampak pencemaran (Mila, 2009). 
Dampak pencemaran berasal dari pembusukan sampah yang menghasilkan limbah cair yang disebut Lindi. Lindi adalah air hasil degradasi dari sampah dan dapat menimbulkan pencemaran apabila tidak diolah terlebih dahulu sebelum di buang ke lingkungan (Mila, 2009).

Melihat lokasi pembuangan sampah akhir Telaga Punggur yang aksesnya sangat dekat dengan laut, tidak menutup kemungkinan bila curah hujan tinggi akan menambah volume air Lindi dan bisa saja melimpas (run-off) ke laut sebelum diolah. Menurut hasil penelitian Mila (2009) diperoleh hasil bahwa lindi dari Instalasi Pengolahan Air Limbah (IPAL) Telaga Punggur, belum efektif menurunkan kadar logam terlarut (TDS). Tetapi dibeberapa tempat pembuangan akhir sampah salah satunya di TPA Rawa Kucing Kabupaten Tangerang, air lindi potensial dijadikan pupuk cair (Puspita, 2007).

Penelitian ini dimaksudkan untuk memanfaatkan potensi air Lindi dari tempat pembuangan akhir sampah Telaga Punggur Batam menjadi pupuk organik cair. Untuk melihat pengaruh pupuk organik cair yang dibuat dari bahan air Lindi, pupuk tersebut perlu diuji coba. Penelitian uji coba dilakukan pada tanaman Seledri (Apium graveolens L) dengan melihat pertumbuhan morfometrik tanaman.

Tanaman Seledri merupakan salah satu jenis sayuran daun yang sudah lama dikenal oleh masyarakat.Seledri mempunyai aroma yang khas untuk menyedapkan masakan. Seledri merupakan tanaman banyak manfaat serta dapat dimodifikasi sebagai tanaman hias dan obat (Muhlisah, 1997).Tanaman Seledri juga mengandung emustral dan cholesterol yang digunakan untuk menyuburkan dan menghitamkan rambut. Seledri dapat digunakan sebagai bahan shampo dan cream bath (Permadi, 2006). Sebagai rumusan masalah dalam penelitian ini yaitu apakah ada pengaruh pemberian pupuk organik cair berbahan dasar air Lindi dari tempat pembuangan akhir sampah Telaga Punggur Batam terhadap pertumbuhan morfometrik tanaman Seledri (Apium graveolens L), berapakah dosis optimum yang digunakan dalam pemupukan tanaman Seledri sehingga memberikan hasil yang baik dengan gambaran tingkat pertambahan tinggi dan jumlah daun lebih banyak dan apakah pemberian pupuk organik cair air Lindi memberikan hasil pertambahan tinggi dan jumlah daun tanaman Seledri yang berbeda dengan pupuk organik cair yang ada di pasaran sebagai pupuk pembanding. 
Adapun tujuan dari penelitian ini adalah membuktikan adanya pengaruh pemberian pupuk organik cair berbahan dasar air Lindi dari tempat pembuangan akhir sampah Telaga Punggur Batam terhadap pertumbuhan morfometrik tanaman Seledri (Apium graveolens, L), mengetahui dosis optimum yang digunakan dalam pemupukan tanaman Seledri sehingga memberikan hasil yang baik dengan gambaran tingkat pertambahan tinggi dan jumlah daun lebih banyak, mengetahui perbandingan tingkat pertumbuhan tanaman Seledri yang diberikan perlakuan pupuk organik cair berbahan dasar air Lindi dengan pupuk organik lain yang dipakai petani.

\section{METODOLOGI}

Penelitian dilakukan pada bulan April s/d Juni 2013 menggunakan jenis penelitian eksperimen. Penelitian diawali dengan pengambilan sampel air Lindi dari Instalasi Pengolahan Air Limbah (IPAL) tempat pembuangan akhir sampah Telaga Punggur Batam. Kandungan organik unsur hara dari air Lindi tempat pembuangan akhir sampah Telaga Punggur Batam yang sudah diolah menjadi pupuk organik cair, dianalisis memanfaatkan biro jasa analis Laboratorium Produktivitas Lingkungan Institut Pertanian Bogor.

Alat dan bahan yang digunakan seperti jerigen isi 10 liter 2 buah, gayung bertangkai 1 buah, ember hitam kapasitas 70 liter, batang pengaduk dari kayu, pot berdiameter $15 \mathrm{~cm}$ dan tinggi $20 \mathrm{~cm}$ sejumlah 20 pot, kotak semai ukuran $50 \mathrm{~cm}$ x $20 \mathrm{~cm}$ x $10 \mathrm{~cm}$, gelas piala ukuran $250 \mathrm{ml}$, paranet untuk pagar lokasi tanam, gunting, alat penyiram tanaman dan air lindi 20 liter serta bakteri starter (azotobacter, lactobacillus, streptomyces) 1 liter, glukosa/gula pasir secukupnya).

Data penelitian diolah dengan menggunakan statistik inferensial yaitu teknik statistik parametrik dengan Uji T (uji hipotesis) sampel kurang dari tiga puluh. Dengan membandingkan dua sampel yang berbeda dengan taraf signifikan $\alpha=0,05$. Pengumpulan data dilakukan sesuai parameter pengamatan yaitu pertumbuhan morfometrik tinggi tanaman dan jumlah daun tanaman Seledri (Apium graveolens L). Hipotesis penelitian dirumuskan dengan $\mathrm{H}_{0}$ dan $\mathrm{H}_{\mathrm{i}}$. Adapun asumsi sementara menolak $\mathrm{H}_{0}$ dan menerima $\mathrm{H}_{1}$ apabila: $\mathrm{t}_{\text {hitung }}>\mathrm{t}\left(\alpha_{\text {,df }}\right.$ dengan $\mathrm{df}=\mathrm{n}_{1}+\mathrm{n}_{2}-2$. Menerima $\mathrm{H}_{0}$ dan Menolak $\mathrm{H}_{1}$ apabila $\mathrm{t}_{\text {hitung }}$ $<\mathrm{t}_{(} \alpha$, df $)$ dengan $\mathrm{df}=\mathrm{n}_{1}+\mathrm{n}_{2}-2$. 


\section{PEMBAHASAN}

Hasil dari penelitian ini adalah untuk melihat pertambahan tinggi tanaman dan jumlah daun tanaman Seledri. Didapatkan data pengamatan tinggi daril pengamatan I, II dan III ternyata pertambahan tinggi tanaman Seledri memakai pupuk organik cair Lindi dengan pupuk organik cair pembanding tidak sama. Ilustrasi data perbandingan total pertambahan tinggi disajikan dalam bentuk boxplot data, membandingkan dua data independen yang tidak berpasangan sebagai berikut.

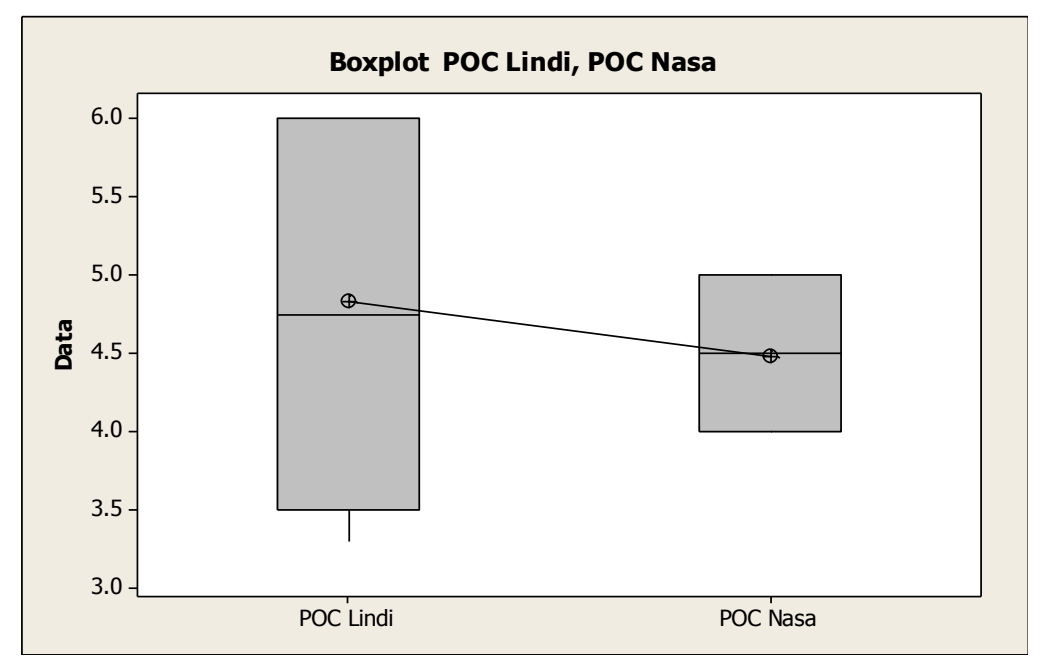

Gambar 1. Boxplot Data Uji T Tinggi Total Tanaman Seledri

Tabel 1. Hasil Analisis Data Uji Air Lindi dengan POC Nasa

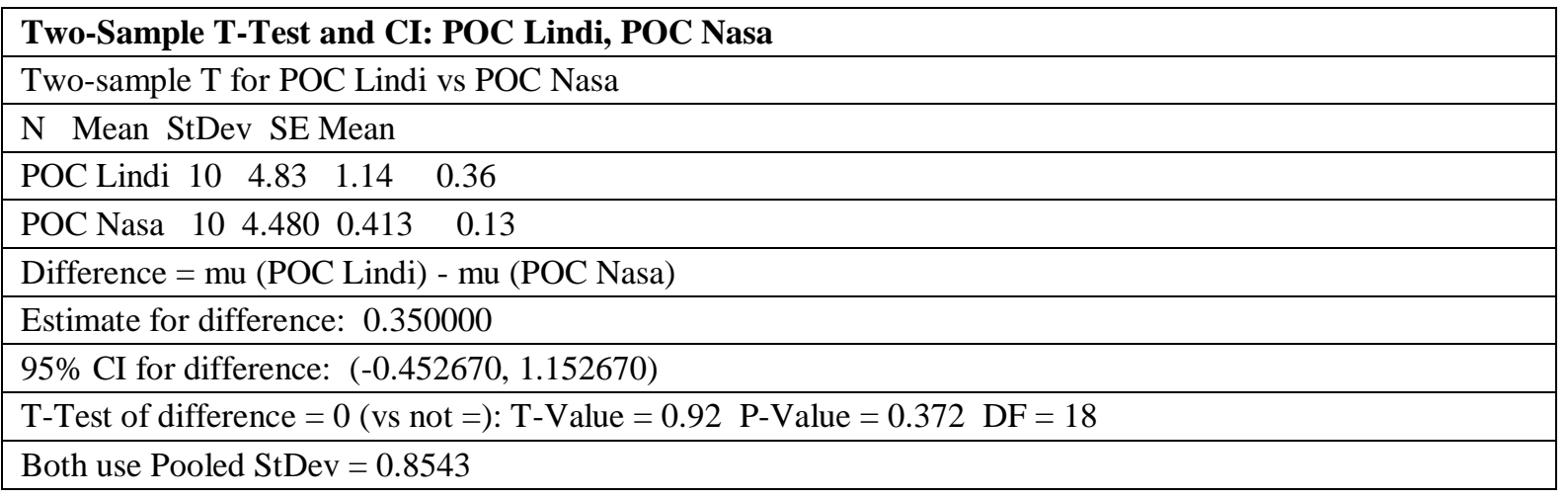

Derajat bebas dari data pengamatan tinggi adalah 18. Apabila ditetapkan level kepercayaan 95\% atau level toleransi 0,05. Maka T tabel adalah T(0,05;18 adalah 1,734. Pada output minitab terlihat $\mathrm{T}$ hitung adalah 0,92 . Karena $\mathrm{T}$ hitung $<\mathrm{T}$ tabel, maka $\mathrm{H}_{0}$ 
diterima, artinya Pupuk organik cair Lindi memberikan pengaruh yang sama dengan pupuk organik cair pembandingnya terhadap pertambahan tinggi tanaman Seledri (Apium graveolens $L$ ). Dari output minitab juga terlihat rata-rata tinggi tanaman Seledri dengan pupuk cair Lindi 4,83 dan pupuk cair pembanding 4,48. Pupuk cair Lindi dalam total pertambahan tinggi tanaman Seledri memberikan hasil pertambahan tinggi yang lebih baik dari pupuk pembandingnya. Menurut Syahrudin (2012), menyebutkan bahwa pada saat pertumbuhan tanaman seperti pertambahan tinggi sangat dipengaruhi oleh faktor genetik dan ketersediaan unsur hara di dalam jumlah yang cukup dan berimbang. Menurut Lingga dan Marsono (2001) dalam Syahrudin (2012) unsur Nitrogen sangat penting untuk pertumbuhan vegetatif tanaman karena dapat merangsang pertumbuhan secara keseluruhan. Menurut Hindersah dan Simarmata (2004) dalam Syahrudin (2012) ketersediaan Nitrogen adalah penting pada saat pertumbuhan tanaman, karenaNnitrogen berperan dalam proses biokimia tanaman.

Selain dari Nitrogen, untuk meningkatkan pertambahan tinggi tanaman Seledri dibutuhkan unsur Fosfo.Unsur Kalium dibutuhkan di dalam memacu pertumbuhan tinggi tanaman.Dari unsur hara yang dibutuhkan tanaman untuk pertumbuhan yang paling menentukan adalah unsur Nitrogen, apalagi untuk tanaman Seledri yang mempunyai nilai jual yang ekonomis.Ketersediaan unsur Nitrogen pada pupuk organik cair Lindi diduga berperan langsung didalam pertambahan tinggi tanaman Seledri (Apium graveolens L).

Untuk mendapatkan hasil yang baik maka pemakaian dosis harus diperhatikan.Untuk tanaman Seledri membutuhkan unsur Nitrogen yang lebih, dibandingkan dengan unsur Fosfor dan Kalium. Karena itu dosis yang digunakan untuk memperkaya Nitrogen tiga kali lipat dari dosis pupuk pembandingnya untuk menyetarakan kandungan unsur nitrogen.

Unsur kalium merupakan salah satu unsur hara yang sangat berperan dalam memacu pertumbuhan tinggi tanaman.Berdasarkan hasil analisis laboratorium, dari sampel pupuk organik cair Lindi yang dianalisis ternyata kandungan unsur Kalium cukup tinggi 
menyebabkan pertambahan jumlah daun tanaman Seledri pupuk organik cair Lindi lebih baik dari pupuk organik cair pembandingnya. Ilustrasi data perbandingan total pertambahan jumlah daun pupuk organik cair Lindi dan pupuk organik cair pembanding disajikan dalam bentuk boxplot data, membandingkan dua data independen.

Pada gambar 2 dibwah tampak derajat bebas $(\mathrm{dB})$ dari data pengamatan total jumlah daun adalah 18. Apabila ditetapkan level kepercayaan 95\% atau level toleransi 0,05. Maka T tabel adalah $\mathrm{T}(0,05 ; 18$ adalah 1,734. Pada output minitab terlihat $\mathrm{T}$ hitung adalah 2,09. Karena $\mathrm{T}$ hitung $>\mathrm{T}$ tabel, maka $\mathrm{H}_{0}$ ditolak, artinya Pupuk organik cair Lindi memberikan hasil yang tidak sama dengan pupuk organik cair pembandingnya terhadap pertambahan jumlah daun tanaman Seledri (Apium graveolens $L$ ).

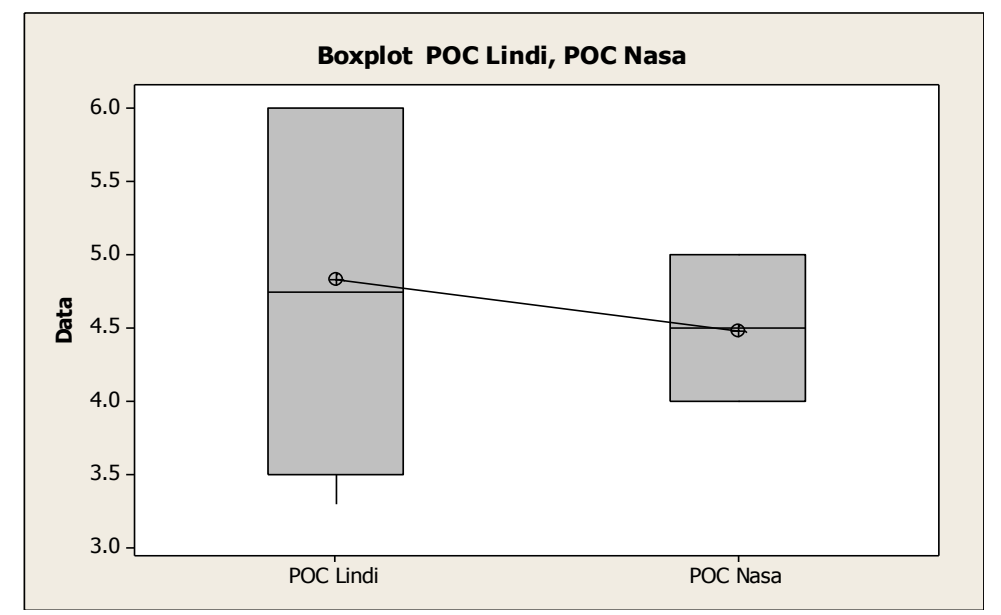

Gambar 2. Boxplot Data Uji T Total Jumlah Daun Tanaman Seledr

Tabel 2. Hasil Analisis Data Jumlah Daun Perlakuan Uji Air Lindi dengan POC Nasa

\begin{tabular}{|c|}
\hline Two-Sample T-Test and CI: POC Lindi, POC Nasa \\
\hline Two-sample T for POC Lindi vs POC Nasa \\
\hline N Mean StDev SE Mean \\
\hline $\begin{array}{lllll}\text { POC Lindi } 10 & 5.500 & 0.527 & 0.17 \\
\end{array}$ \\
\hline $\begin{array}{lllll}\text { POC Nasa } & 10 & 4.900 & 0.738 & 0.23\end{array}$ \\
\hline Difference $=$ mu (POC Lindi) - mu (POC Nasa) \\
\hline Estimate for difference: 0.600000 \\
\hline 95\% CI for difference: $(-0.002427,1.202427)$ \\
\hline T-Test of difference $=0($ vs not $=):$ T-Value $=2.09 \mathrm{P}-$ Value $=0.051 \mathrm{DF}=18$ \\
\hline Both use Pooled StDev $=0.6412$ \\
\hline
\end{tabular}


Dari hasil penelitian dilakukan pembahasan dengan referensi yang ada.yaitu dengan bertambahnya jumlah daun berakibat meningkatnya luas daun secara keseluruhan. Hal ini berarti kemampuan tanaman melakukan fotosintesis meningkat. Selain itu pertambahan jumlah daun juga berakibat pada pertambahan biomassa secara keseluruhan.

Dari Gambar 2, dapat dilihat bahwa pengaruh pupuk organik cair Lindi terhadap pertambahan jumlah daun lebih baik dari pupuk organik cair pembandingnya. Hal ini karena kandungan Nitrogen dalam jumlah yang lebih, diduga sangat berperan langsung memicu pertambahan jumlah daun (Syahrudin, 2012). Pernyataan Lakitan (1996) dalam Simatupang (2012) bahwa pada waktu pertumbuhan daun, tidak semua unsur hara diperlukan dan berperan langsung terhadap pertumbuhan daun.Unsur hara yang paling berpengaruh terhadap pertumbuhan dan perkembangan daun adalah Nitrogen.

Unsur nitrogen merupakan unsur hara utama bagi pertumbuhan bagian-bagian vegetatif tanaman seperti daun, batang dan akar.Sehingga pertambahan jumlah daun tanaman Seledri menggunakan pupuk organik cair Lindi sedikit lebih baik dari pupuk organik cair pembandingnya.

Menurut Rosmarkan dan Yuwono (2002) dalam Syahrudin (2011) bahwa Fosfor yang dianggap penting dalam pembentukan energi sel (ATP) yang terbentuk pertama kali pada proses fosforilisasi pada proses fotosintesis daun. Unsur kalium (K) terlibat dalam mereduksi $\mathrm{CO}_{2}$ dalam proses fotosintesis pada daun. Dari hasil analisis laboratorium produktivitas lingkungan Institut Pertanian Bogor, nilai unsurKalium sangat tinggi dibandingkan dengan unsur yang lainnya. Dari hasil penelitian ini ternyata air lindi yang diambil dari tempat pembuangan akhir sampah kota Batam yang berlokasi di daerah Telaga Punggur, dapat diolah menjadi pupuk organik cair. Karena dari penelitian membandingkan hasil pertumbuhan dengan menggunakan pupuk organik cair pembanding yang biasa digunakan petani menunjukkan hasil pupuk organik cair lindi memberikan hasil lebih baik terhadap pertumbuhan morfometrik pertambahan tinggi dan jumlah daun tanaman Seledri (Apium graveolens L). 


\section{KESIMPULAN}

Dari hasil penelitian disimpulkan bahwa pemberian pupuk organik cair berbahan dasar air Lindi dari Tempat Pembuangan Akhir ( TPA) Sampah Telaga Punggur Batam yang diujikan pada tanaman Seledri (Apium graveolens L) memberikan hasil yang sama terhadap morfometrik tinggi tanaman Seledri dengan menggunakan pupuk organik cair pembanding yang dipakai petani.

Dan memberikan hasil yang tidak sama terhadap pertambahan jumlah daun tanaman Seledri dengan pupuk organik cair pembanding yang dipakai petani. Pupuk organik cair Lindi memberikan hasil lebih baik terhadap morfometrik jumlah daun tanaman Seledri.

\section{REFERENSI}

Mila TS.2009. Evaluasi Kadar TDS, Cadmium, Dan MPN Coliform Pada Lindi Sebelum Dan Sesudah Pengolahan Pada Instalasi Pengolahan Air Limbah (IPAL) Di TPA Telaga Punggur Nongsa Kota Batam. [skripsi]. Universitas Dipenogoro. eprints.undip.ac.id/30304. 20 Mei 2013.

Muhlisah, F. 1997. Pemanfaatan Tanaman seledri Untuk Obat, Buletin Minggu ke II Juni 1997. Yayasan Pers Indonesia-Jakarta.

Permadi, A. 2006. 36 Resep Tumbuhan Obat Untuk Menurunkan Kolesterol. Penebar Swadaya. Jakarta.

Puspita L. 2007.Reduksi Senyawa Nitrogen, Fosfor, Konstituen Organik, Dan TSS Pada Air Lindi Limpasan dengan Rawa Buatan [tesis]. Bogor: Sekolah Pasca Sarjana Institut Pertanian Bogor.

Riansyah E, Wesen P. 2012. Pemanfaatan Lindi Sampah Sebagai Pupuk Cair [jurnal]. Prodi Teknik Lingkungan.Universitas Pembangunan Nasional. Jawa Timur. eprints.upnjatim.ac.id/4243/1/(2)JURNAL_Putu.pdf . 20 Mei 2013

Simatupang LA. 2012. Pengaruh Pemberian Pupuk Organik Cair Pada Tanaman Selada[skripsi]. Batam: Universitas Riau Kepulauan, Fakultas Keguruan dan Ilmu Pendidikan.

Syahrudin. 2011. Respon Tanaman Seledri (Apium graveolens L) Terhadap Pemberian Beberapa Macam Pupuk Daun Pada Tiga Jenis Tanah.[Jurnal] Universitas Palangkaraya, Fakultas Pertanian. http://jurnalagriepat.wordpress.com diakses 23 Mei 2013 